\title{
Prototipe Sistem Keamanan Rumah Berbasis Web dan SMS Gateway
}

\section{The Prototype of Home Security System Based on Web and SMS Gateway}

\author{
Eki Ahmad Zaki Hamidi ${ }^{1 *}$, Mufid Ridlo Effendi ${ }^{2}$, M. Rizki Ramdani ${ }^{3}$ \\ 1,2,3 Jurusan Teknik Elektro Fakultas Sains dan Teknologi UIN Sunan Gunung Djati Bandung \\ Jalan AH. Nasution 105 Bandung 40614 telp. (022) 7800525/fax (022) 7803936 \\ ekiahmadzaki@uinsgd.ac.id ${ }^{1 *}$, mufid.ridlo@uinsgd.ac.id², rizkiramdani5@gmail.com ${ }^{3}$
}

\begin{abstract}
Abstrak - Kenyamanan sebuah rumah tinggal perlu didukung oleh sistem keamanan yang tersistematis dan dapat dimonitor dari jarak jauh. Modul SIM800L sebagai media komunikasi SMS dan Web sebagai antarmuka dapat digunakan sebagai alat untuk monitoring rumah secara jarak jauh. Penelitian ini bertujuan membangun prototipe sistem keamanan rumah berbasis web dan SMS gateway. Metode yang digunakan dalam penelitian ini menggunakan pendekatan riset pengembangan (RnD). Penelitian ini menggunakan Arduino dan mikrokontroller Atmega2560 yang berfungsi mengambil data dari sensor PIR serta menjadi input untuk buzzer yang berfungsi sebagai alarm. Jangkauan dan respon PIR diuji dalam beberapa kondisi suhu ligkungan yang berbeda. Modul SIM800L akan mengirimkan SMS bagi pengguna. Untuk melihat kondisi ruangan rumah, tracking IP Camera dilakukan menggunakan motor servo. Pengujian menunjukan bahwa sensor PIR mampu melacak setiap pergerakan dengan suhu 27 derajat celcius pada radius pergerakan 4-7 meter dengan delay rata-rata 2 detik. Mikrokontroller mengirimkan perintah ke buzzer untuk membunyikan alarm dan SMS akan terkirim pada pengguna. Monitoring juga dapat dilakukan pengguna melalui web. Prototipe sistem yang dikembangkan dapat berjalan sesuai dengan target.
\end{abstract}

Kata Kunci: Sistem keamanan rumah, Web, SMS, sensor PIR, kamera.

\begin{abstract}
In order to get a home comfort, it needs to be supported by a systematic security system that could be monitored remotely. SIM800L module as SMS-based communication media and Web technology as a monitoring interface can be used as a tool for remote home monitoring. This study aims to build a prototype of a home security system based on web technology and SMS gateway. The method used in this study uses a development research (RnD) approach. We used Arduino and Atmega2560 microcontroller to retrieve data from the PIR sensor as well as an input for the buzzer that functions as an alarm. The range and response of the PIR sensor are tested under several different ambient temperature conditions. Meanwhile, SIM800L module is used for sending SMS to users. To see the condition of the room of the house, tracking the IP Camera is done using a servo motor. The testing result shows that the PIR sensor can track every movement with a temperature of 27 degrees Celsius at a 4-7 meter movement radius with an average delay of 2 seconds. The microcontroller sends a command to the buzzer to sound an alarm and an SMS will be sent to the user. System monitoring can be seen by users via the web. Generally, the developed system prototype can run according to the target.
\end{abstract}

Keywords: Home security system, web, SMS, PIR sensor, camera.

TELKA, Vol.6, No.1, Mei 2020, pp. 56 65

ISSN (e): 2540-9123

ISSN (p): 2502-1982 


\section{Pendahuluan}

Sistem pengamanan ruangan dalam rumah dengan cara konvensional menggunakan kunci dan penjaga, selain memiliki kelebihan, juga memiliki kekurangan. Diantara kekurangannya adalah tidak dapat dimonitor dari jarak jauh [1]. Pengamanan rumah dengan cara menugaskan seorang penjaga keamanan atau menggunakan kamera $C C T V$ untuk memantau, atau bahkan bunyi alam untuk membantu mempercepat bantuan keamanan, tetap tidak bisa memberikan notifikasi/pemberitahuan secara langsung kepada pemilik rumah ketika ada pencuri [2]. Pemanfaatan $C C T V$ yang hanya merekam saat kejadian juga tetap dapat menjadi celah bagi pelaku pencurian karena tidak ada notofikasi ke pemilik untuk segera mengatisipasi jika ada pencurian [3] [4]. Untuk mengatasi kekurangan yang ada, berbagai macam pengembangan teknologi pengamanan ruangan sudah dikembangkan dengan beragam teknologi dan pendekatan. Pengembangan dan pemanfaatan teknologi dengan merancang sistem keamanan dapat memberikan rasa aman dan nyaman pemilik rumah, juga dapat menekan tindakan kriminalitas khususnya tindak kejahatan pencurian yang sering terjadi ketika rumah ditinggal pemiliknya [5]. Beragam sistem keamanan rumah dapat dikembangkan dengan berbasis relay [6], sensor gerak PIR [7], kamera [8], dan lainnya. Teknologi komunikasi untuk pemantauan yang digunakan juga bisa beragam, mulai dari teknologi seluler [1] salahsatunya dengan SMS [9], Telegram [4], dan Internet of Things (IoT) [8].

Berbagai penelitian menawarkan sistem untuk memberikan keamanan di rumah diantaranya adalah penelitian yang dilakukan Muhamad Irfan Kurniawan dkk [4]. Pada makalahnya dijelaskan sebuah pengembangan sistem keamanan berbasis Internet of Things, dengan prosesor dan kontroler menggunakan Raspberry Pi dan komunikasi menggunakan Telegram Messenger. Sistem memanfaatkan sensor PIR yang dapat mendeteksi adanya manusia. Jika sensor aktif, maka akan memicu kamera yang terhubung dengan Raspberry $P i$ untuk mengambil foto dan mengirimkan gambar tersebut kepada pemilik rumah melalui aplikasi Telegram Messenger [4]. Penelitian lainnya yang ditulis Lia Kamelia, dkk dalam [9] menjelaskan contoh implementasi $e$ Key berbasis SMS, yaitu sistem keamanan menggunakan kunci elektronik dengan menggunakan arduino sebagai prosesor untuk kontrol kunci pintu yang diketik melalui keypad dan SMS gateway [9]. Pengembangan serupa tetapi dengan kontroller dan sensor yang berbeda dilakukan oleh Ade Mubarok, dkk [10]. Pada penelitian [10] sistem keamana rumah dikembangkan berbasis RFID, Sensor PIR dan Modul GSM dan mikrokontroler ATmega328.

Melihat berbagai penelitian yang ada, penggunaan SMS memungkinkan sistem bisa diakses lebih luas, sementara dengan basis layanan lain, beberapa daerah memiliki sinyal yang lemah. Sementara untuk melakukan monitoring, perlu mikrokontroler yang memiliki kapasitas lebih besar dari sebelumnya (ATMEGA328) tetapi juga tidak perlu yang terlalu besar. Oleh karena itu, pada makalah ini dibahas penelitian pengembangan sistem keamanan rumah berbasis web dan SMS gateway dengan mikrokontroler menggunakan ATMEGA 2560. Penelitian ini memanfaatkan sensor PIR yang dapat mendeteksi adanya manusia. Ketika sensor menangkap pergerakan maka mikrokontroler yang mendapat informasi dari sensor akan memberikan notifikasi melalui SMS gateway, setelah itu mengaktifkan buzzer dan memberikan alarm serta akan memicu kamera yang terhubung ke mikrokontroler untuk mengambil gambar dan mengirimkan video streaming melalui web. Pemilik rumah dapat mengakses dari jarak jauh. Dalam melakukan penjejakan pergerakan orang, digunakan servo sebagai tracking camera. Dengan kombinasi ini, diharapkan terbangun sistem keamanan yang tidak terlalu kompleks tapi cukup memadai dalam mengantisipasi pencurian.

\section{Metode Penelitian}

Metode yang digunakan dalam penelitian ini adalah metode penelitian dan pengembangan atau dikenal dengan istilah Research \& Development $(R \& D)$, yaitu metode penelitian yang digunakan untuk menghasilkan produk tertentu yang dalam penelitian dan pengembangan tahapan-tahapannya merupakan suatu siklus yang meliputi kajian terhadap berbagai temuan penelitian lapangan yang berkaitan dengan produk yang akan dikembangkan. 
Tahapan yang dilakukan untuk memperoleh hasil yang diinginkan dalam merancang prototipe sistem keamanan rumah dibuat dalam bentuk flowchart seperti pada Gambar 1,

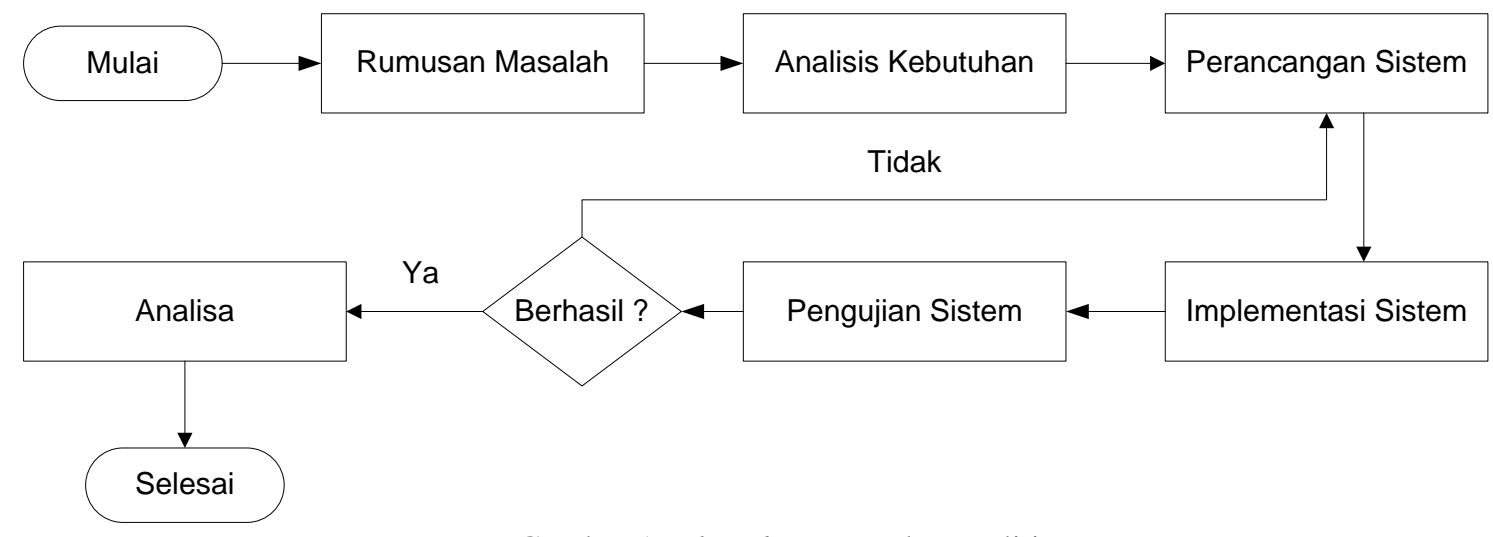

Gambar 1. Flowchart metode penelitian

Gambar 1 menggambarkan langkah yang ditempuh dalam penelitian ini, mulai dari rumusan masalah. Dari rumusan masalah dapat dianalisa kebutuhan dalam penelitian ini, yaitu kebutuhan perangkat keras dan kebutuhan perangkat lunak untuk perancangan prototipe sistem keamanan rumah berbasis web dan SMS gateway. Langkah selanjutnya pengujian sistem dan dianalisa hasil pengujian.

\section{Hasil dan Pembahasan}

Dalam penelitian ini hanya berbentuk desain dan prototipe sistem yang dibangun, namun disesuaikan dengan kondisi yang sesungguhnya. Kemudian dievaluasi supaya mendapatkan feedback pada rancangan interaktif yang dibangun terkait kelebihan dan kekurangan desain.

\subsection{Desain dan Realisasi Sistem}

Rancangan sistem yang dibuat diperlihatkan pada Gambar 2. Prinsip kerja dari sistem ini adalah sensor PIR akan mendeteksi gerak dan dikirim ke microcontroller. Jika sensor PIR mendeteksi gerakan, maka microcontroller akan mengaktifkan buzzer dan mengirimkan notifikasi melalui SMS. Pada saat bersamaan kamera akan merekam pergerakan objek yang didekteksi oleh sensor PIR. Hasil rekaman kamera akan dikirimkan ke web server sebagai video streaming.

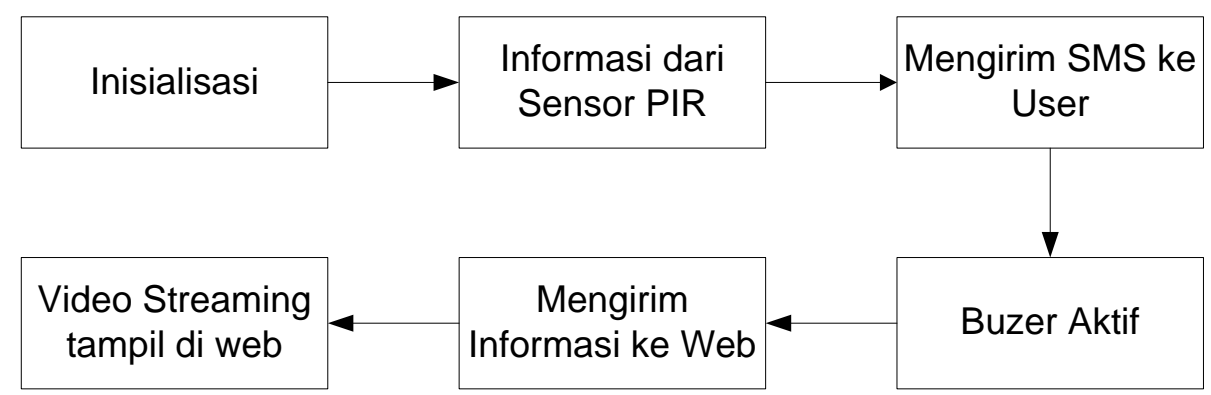

Gambar 2. Prinsip kerja sistem

Rancangan perangkat keras yang digunakan pada sistem ini diperlihatkan pada Gambar 3, 


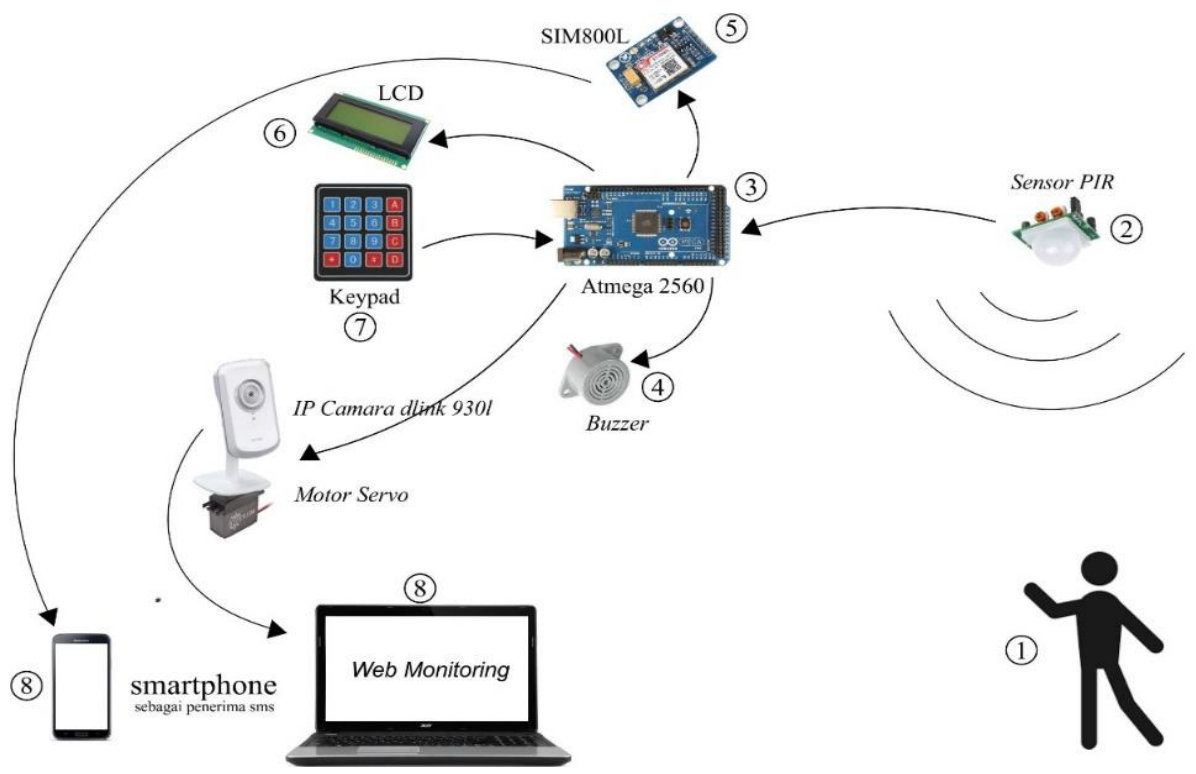

Gambar 3. Diagram blok desain perangkat keras

Perangkat keras yang digunakan pada rancangan sistem ini dapat dilihat pada Tabel 1 . Sementara rangkaian dan realisasinya dapat dilihat pada Gambar 4 dan Gambar 5.

Tabel 1. Komponen yang digunakan.

\begin{tabular}{ccc}
\hline No & Komponen & Jumlah \\
\hline 1 & Arduino Mega 2560 & 1 \\
2 & SIM800L & 1 \\
3 & IP Camera & 1 \\
4 & Buzzer & 1 \\
5 & Motor Servo & 1 \\
6 & LCD & 1 \\
7 & Keypad & 1 \\
\hline
\end{tabular}
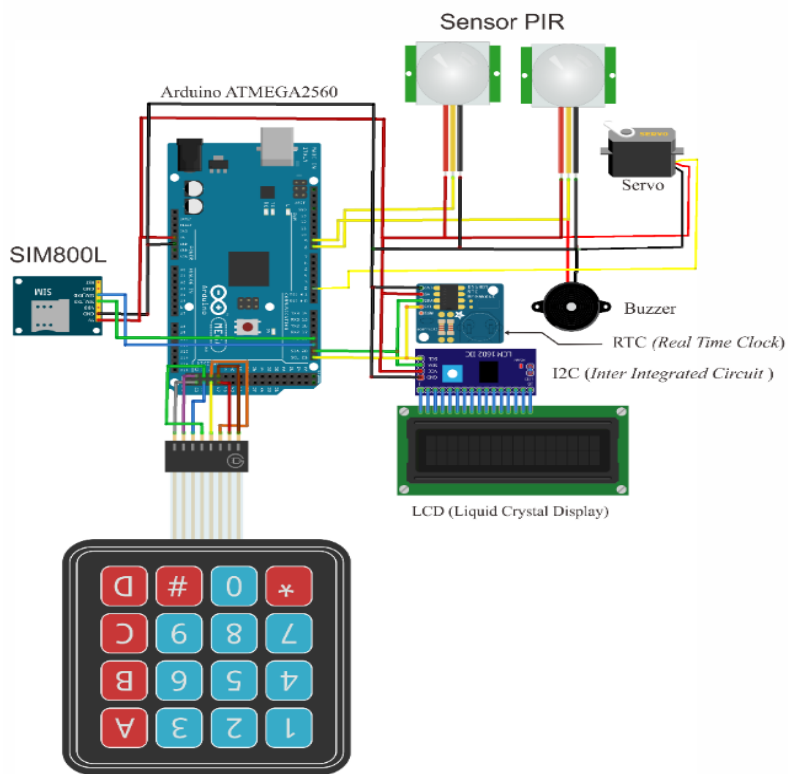

Gambar 4. Rangkaian perangkat keras. 


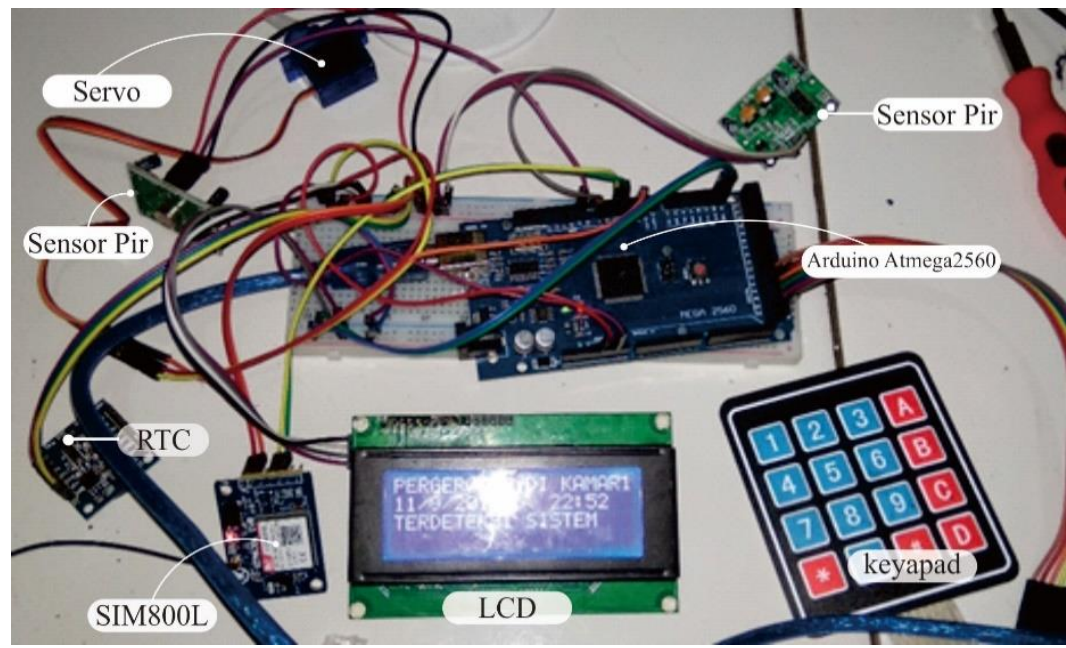

Gambar 5. Implementasi perangkat keras sistem.

Ketika sudah aktif, sistem akan membaca data dari sensor PIR. Sensor PIR mendeteksi ada atau tidaknya pergerakan. Jika ada gerakan, servo akan bergerak mengikuti arah gerakan. Pada saat yang sama buzzer akan diaktifkan dan sistem mengirim SMS notifikasi ke pemilik rumah. Selain notifikasi yang dikirimkan sistem ke pemilik rumah, kondisi keamanan juga bisa dimonitor melalui web. Secara singkat, alur kerja sistem digambarkan pada flowchart perangkat lunak yang diperlihatkan pada Gambar 6, sementara Tampilan web untuk monitoring ditunjukkan oleh Gambar 7.

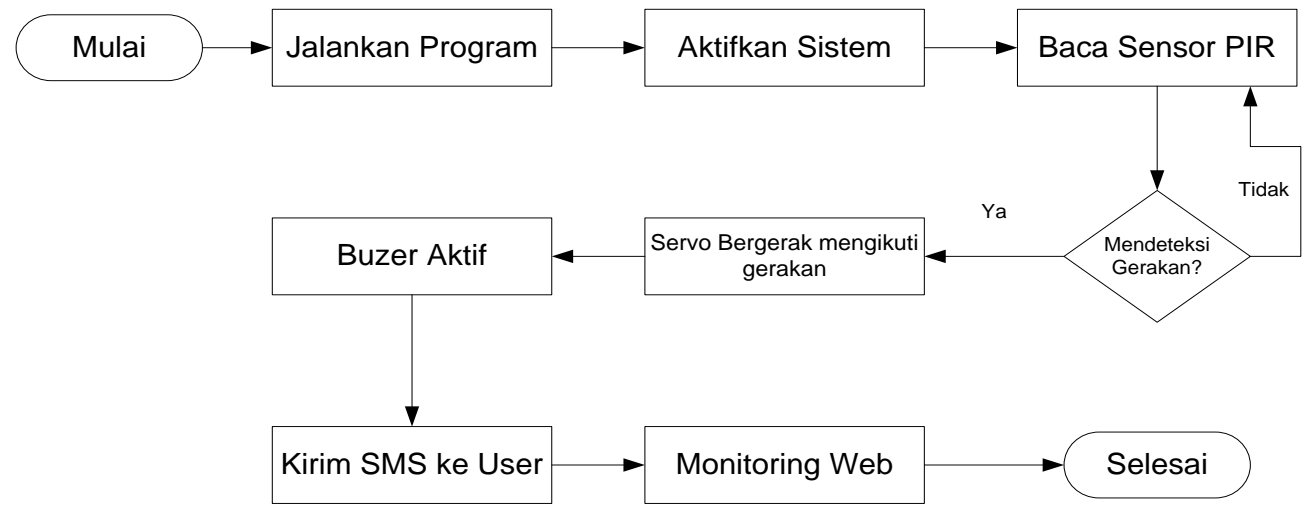

Gambar 6. Algoritma program.

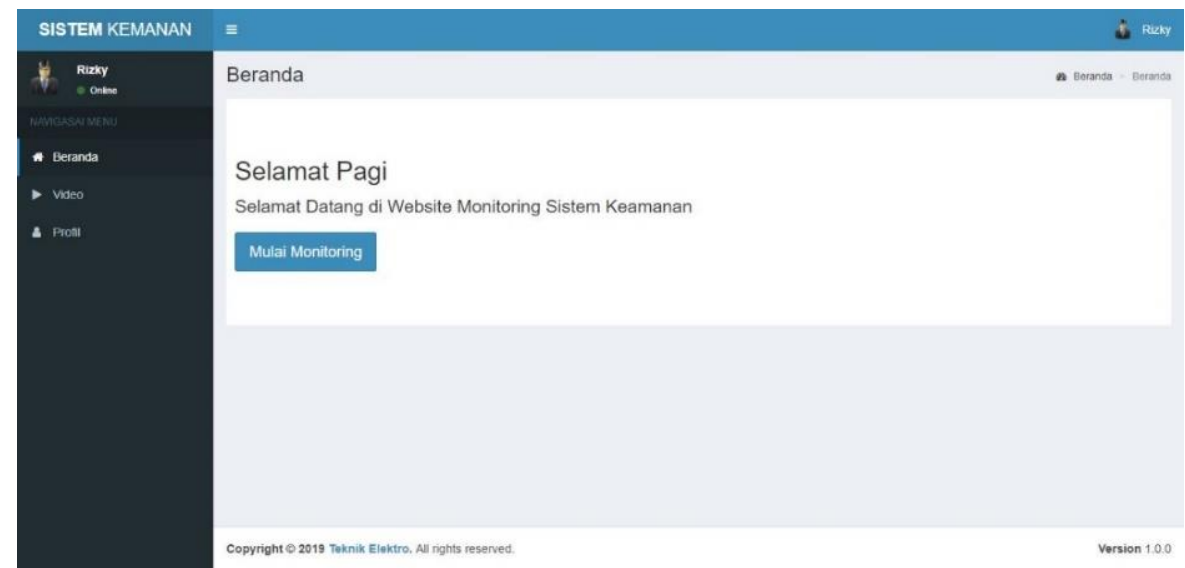

Gambar 7. Tampilan beranda web untuk monitoring. 
Pemrograman Arduino menggunakan IDE yang sudah disediakan oleh Arduino. Database yang digunakan untuk menyimpan username dan password menggunakan mysql. Sementara pemrograman web menggunakan HTML dan PHP.

\subsection{Pengujian dan Analisis}

Untuk mengetahui kemempuan sistem yang sudah dibuat, maka dilakukan pengujian. Pengujian yang dilakukan meliputi pengujian pengaktifan sistem, pengujian sensor PIR, pengujian pengiriman SMS, pengujian web, pengujian respon waktu motor servo, dan pengujian buzzer.

\subsubsection{Pengaktifan Sistem}

Pengujian pengaktifan sistem dilakukan untuk memastikan bahwa sistem hanya dapat diaktifkan oleh pemilik rumah. Pengujian dilakukan dengan memasukan sandi pada sistem. Jika sandi diterima, maka sistem akan aktif sebaliknya jika sandi tidak diterima, maka sistem tidak dapat aktif. Sandi dientrikan dan diakhiri tanda pagar. Pada sistem ini diset sandinya yaitu "1234". Sandi diinputkan melalui keypad yang sudah disediakan. Gambar 8 memperlihatkan tampilan pada LCD jika sandi diterima sedangkan Gambar 9 memperlihatkan tampilan LCD jika sandi tidak diterima. Menonaktifkan sistem dilakukan dengan memasukan kembali sandi pada akhir ujicoba. Gambar 10 memperlihatkan informasi pada layar LCD bahwa sistem tidak aktif. Hasil pengujian memperlihatkan sistem pengkatifan dan penonaktifkan dapat bekerja dengan baik sehingga sistem keamanan hanya bisa diaktifka dan dinon aktifkan oleh pemilik rumah.

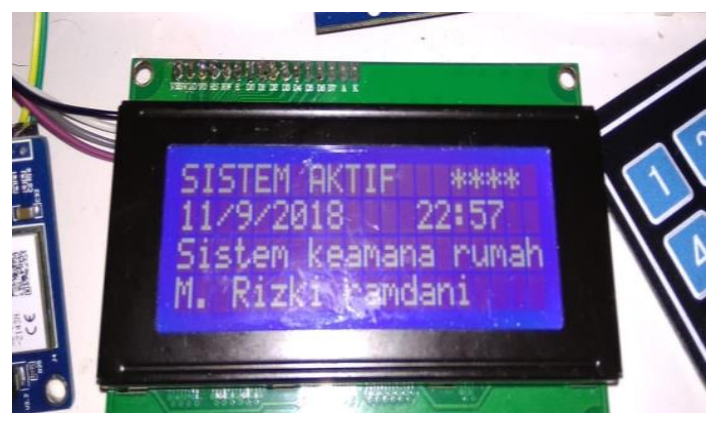

Gambar 8. Sistem menolak saat sandi salah

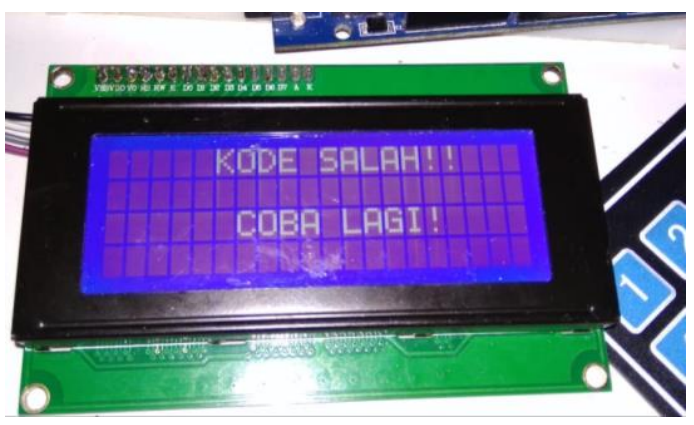

Gambar 9. Sistem aktif

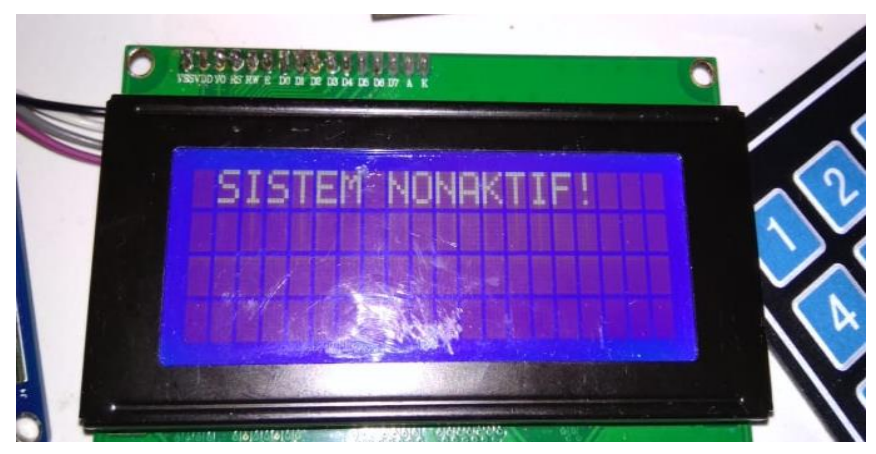

Gambar 10. Sistem nonaktif

\subsubsection{Deteksi Objek dengan Sensor PIR}

Pengujian sensor PIR dilakukan untuk mengetahui jangkauan pembacaan sensor dan respon waktu sensor ketika mendeteksi objek. Pengujian dilakukan dari mulai jarak sangat dekat, sampai pada jangkauan maksimal pembacaan sensor, dengan pengamblan data setiap 1 meter. Gambar 11 memperlihatkan informasi yang ditampilkan di LCD jika objek masih terdeteksi dan hasil pengujian jarak jangkauan sensor diperlihatkan pada Tabel 2. 


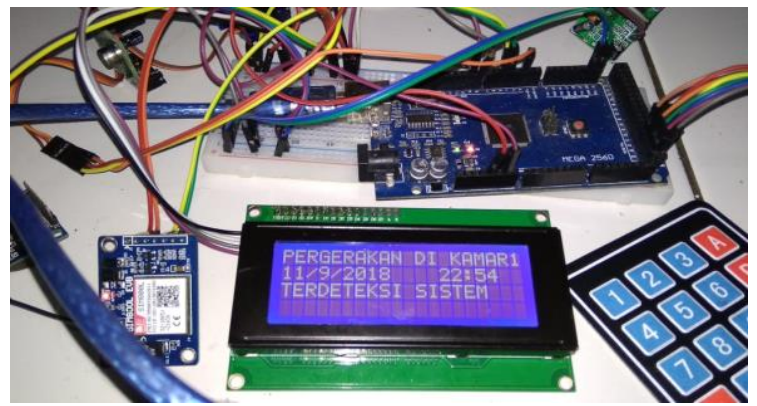

Gambar 11. Tampilan LCD ketika sensor PIR mendeteksi objek

\begin{tabular}{ccc}
\multicolumn{3}{c}{ Tabel 2. Uji jangkauan pembacaan sensor PIR. } \\
\hline Pengujian & Jarak Objek $(\mathrm{m})$ & Hasil \\
\hline 1 & 1 & Terdeteksi \\
2 & 2 & Terdeteksi \\
3 & 3 & Terdeteksi \\
4 & 4 & Terdeteksi \\
5 & 5 & Terdeteksi \\
6 & 6 & Terdeteksi \\
7 & 7 & Terdeteksi \\
8 & 8 & Tidak Terdeteksi \\
9 & 9 & Tidak Terdeteksi \\
10 & 10 & Tidak Terdeteksi \\
\hline
\end{tabular}

Sensor PIR ini diuji pada beberapa suhu lingkungan percobaan, yaitu $27^{\circ} \mathrm{C}, 23^{\circ} \mathrm{C}, 22^{\circ} \mathrm{C}$, dan $21^{\circ} \mathrm{C}$. Jika dibandingkan, sensor akan lebih baik mendeteksi pergerakan pada suhu $27^{\circ} \mathrm{C}$ karena sudah mendekati dengan suhu manusia yaitu 32 derajat. Hal tersebut dipengaruhi oleh prinsip kerja Sensor PIR yaitu bekerja dengan menangkap energi panas yang dihasilkan dari pancaran sinar inframerah pasif yang dimiliki setiap benda dengan suhu benda diatas nol mutlak. Data pada Tabel 2 menunjukan hasil uji pada suhu lingkungan $27^{\circ} \mathrm{C}$.

Pengujian respon waktu merupakan pengujian yang bertujuan untuk mengetahui waktu respon yang dibutuhkan oleh sensor dari mulai ada pergerakan sampai pembacaan. Pengujian dilakukan dengan menggunakan stopwach. Hasil pengujian respon waktu diperlihatkan pada Tabel 3.

Tabel 3. Respon waktu sensor PIR dalam membaca pergerakan.

\begin{tabular}{ccc}
\hline Pengujian & Sensor PIR & Waktu (detik) \\
\hline 1 & Pergerakan 1 & 2,11 \\
2 & Pergerakan 2 & 1,81 \\
3 & Pergerakan 3 & 1,88 \\
4 & Pergerakan 4 & 1,92 \\
5 & Pergerakan 5 & 1,88 \\
6 & Pergerakan 6 & 1,97 \\
7 & Pergerakan 7 & 2,04 \\
8 & Pergerakan 8 & 2,06 \\
9 & Pergerakan 9 & 1,89 \\
10 & Pergerakan 10 & 2,01 \\
Rata-rata Delay & & 1,80 \\
\hline
\end{tabular}

Tabel 3 menunjukkan bahwa jarak maksimal sensor PIR dapat mendeteksi objek adalah 7 meter. Respon waktu sensor PIR masih bisa ditoleransi dengan respon waktu maksimal 2,11 detik. Waktu orang meninggalkan rumah lebih besar dari 2,11 detik sehingga orang yang terdeteksi masih bisa direkam.

\subsubsection{Proses Pengiriman SMS}

Pengujian pengiriman SMS dilakukan untuk melihat apakah sistem dapat mengirimkan SMS jika ada objek yang terdeteksi. Dengan mendekatkan objek pada sistem, sistem harus dapat mengirimkan SMS ke pemilik rumah. Gambar 12 memperlihatkan SMS yang dikirim oleh sistem dan diterima oleh pemilik rumah. 


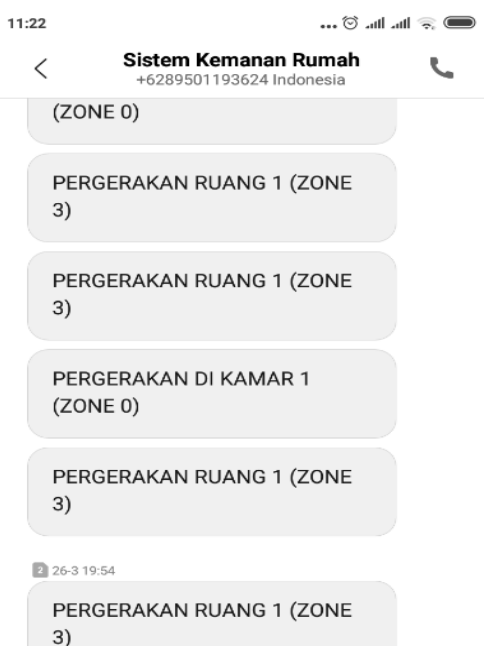

Gambar 12. Pesan yang diterima pada user

\subsubsection{Monitoring Melalui Web}

Proses pengujian web merupakan pengujian yang dilakukan untuk menguji dua hal: pertama, proses autentikasi melalui login; kedua, proses monitoring tayangan video pada web. Pengujian autentikasi dilakukan dengan cara memasukan username dan password. Jika username dan password benar, maka akan masuk pada halaman beranda. Gambar 13 memperlihatkan halaman beranda jika username dan password benar. Setelah berhasil login dapat dilihat tampilan tayangan video yang ditangkap oleh kamera seperti pada Gambar 14. Pengujian menunjukkan bahwa sistem telah dapat membatasi akses ke web oleh pengguna yang sah.

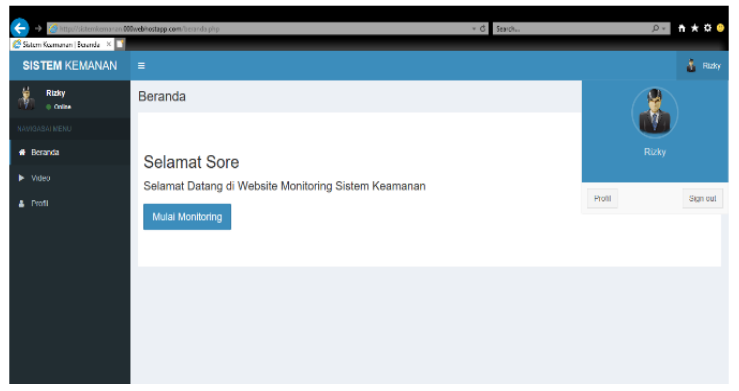

Gambar 13. Tampilan ketika sensor PIR mendeteksi gerak

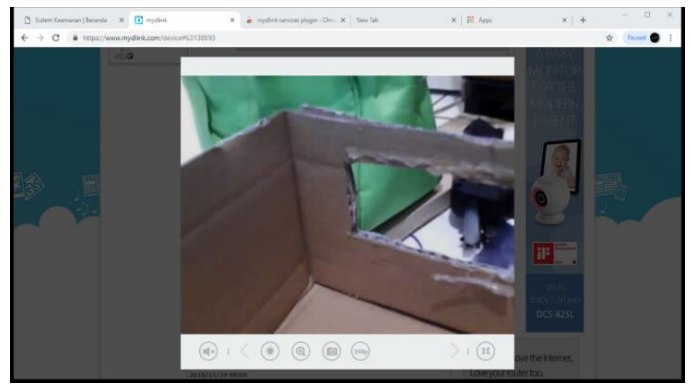

Gambar 14. Tayangan video hasil tangkapan kamera

\subsubsection{Mengatur Arah dengan Motor Servo}

Pengujian motor servo dilakukan untuk melihat respon motor servo ketika diberi perintah untuk bergerak. Hasil pengujian respon motor servo diperlihatkan pada Tabel 4,

Tabel 4. Respon waktu motor servo

\begin{tabular}{ccc}
\hline Pengujian & Motor servo & Waktu (detik) \\
\hline 1 & Pergerakan 1 & 2,01 \\
2 & Pergerakan 2 & 2,13 \\
3 & Pergerakan 3 & 2,00 \\
4 & Pergerakan 4 & 1,86 \\
5 & Pergerakan 5 & 2,17 \\
6 & Pergerakan 6 & 2,10 \\
7 & Pergerakan 7 & 2,10 \\
8 & Pergerakan 8 & 1,85 \\
9 & Pergerakan 9 & 2,01 \\
10 & Pergerakan 10 & 2,03 \\
Rata-rata delay & & 1,8 \\
\hline
\end{tabular}


Respon waktu paling besar dari pengujian sebesar 2,17 detik masih dalam waktu yang ditoleransi, karena pergerakan orang lebih dari waktu maksimal respon waktu motor servo. Hal ini berarti bahwa motor servo masih bisa mengikuti pergerakan orang di ruangan.

\subsubsection{Buzzer}

Sama halnya seperti pengujian motor servo, pengujian buzzer dilakukan untuk melihat respon buzzer ketika diperintahkan untuk berbunyi. Hasil pengujian buzzer diperlihatkan pada Tabel 5,

Tabel 5. Respon waktu respon buzzer

\begin{tabular}{ccc}
\hline Pengujian & Respon Buzzer & Waktu (detik) \\
\hline 1 & Pergerakan 1 & 1,97 \\
2 & Pergerakan 2 & 1,82 \\
3 & Pergerakan 3 & 1,94 \\
4 & Pergerakan 4 & 1,95 \\
5 & Pergerakan 5 & 2,05 \\
6 & Pergerakan 6 & 1,99 \\
7 & Pergerakan 7 & 2,04 \\
8 & Pergerakan 8 & 1,96 \\
9 & Pergerakan 9 & 2,10 \\
10 & Pergerakan 10 & 1,90 \\
Rata-rata Delay & & 1,97 \\
\hline
\end{tabular}

Buzzer akan berbunyi maksimal 2,10 detik setelah diperintahkan untuk berbunyi. Waktu tersebut masih cukup untuk memberi tahu orang di sekitar sementara orang yang dicurigai masih berada di ruangan.

\section{Kesimpulan}

Prototipe sistem keamanan rumah berbasis web dan SMS gateway yang dikembangkan sudah sesuai dengan tujuan yang ingin dicapai dalam perancangan. Sistem ini sudah bekerja pada saat sistem diaktifkan dengan kode aktivasi. Ketika sistem aktif, maka sensor dan komponen yang lainnya akan bekerja. Keakuratan Sensor PIR dan jarak jangkau Sensor PIR bergantung pada suhu disekitar lingkungan percobaan. Sensor akan lebih baik mendeteksi pergerakan pada suhu yang mendekati dengan suhu manusia yaitu $32^{\circ} \mathrm{C}$. Sistem keamanan ini dapat membaca pergerakan dengan jarak 7 meter, dengan rata-rata waktu delay 2 detik dalam merespon pergerakan. Monitoring dapat dilakukan melalui web melalui proses autentikasi terlebih dahulu.

\section{Referensi}

[1] T. Rahajoeningroem and Wahyudin, "Sistem Keamanan Rumah Dengan Monitoring Menggunakan Jaringan Telepon Selular," Jurnal Teknik Elektro Unikom, vol. 1, no. 1, pp. 24-32, 2013.

[2] E. Riyanto, "Sistem Keamanan Rumah Berbasis Android Dengan Rasberry Pi," Jurnal Informatika Upgris, vol. 5, no. 1, pp. 55-59, 2019.

[3] D. D. Hutagalung, "Sistem Monitoring Dan Keamanan Pintu Berbasis Sms Menggunakan Arduino Uno," ESIST, vol. 12, no. 1, pp. 23-26, 2018.

[4] M. I. Kurniawan, U. Sunarya and R. Tulloh, "Internet of Things : Sistem Keamanan Rumah berbasis Raspberry Pi dan Telegram Messenger," ELKOMIKA, vol. 6, no. 1, pp. 1-15, 2018.

[5] D. Firmansyah, E. A. Z. Hamidi and M. R. Effendi, "The implementation of car security system based on sms gateway and gps (global positioning system)," Journal of Physics: Conference Series, vol. 1175, no. 1, pp. 1-8, 2019.

[6] M. Saleh and M. Haryanti, "Rancang Bangun Sistem Keamanan Rumah Menggunakan Relay," Jurnal Teknologi Elektro, vol. 8, no. 2, pp. 87-94, 2017. 
[7] B. Prima, "Perancangan Sistem Keamanan Rumah Menggunakan Sensor PIR (Passive Infra Red) Berbasis Mikrokontroler," Universitas Maritim Raja Ali Haji, Tanjung Pinang, 2013.

[8] T. S. Gunawan, I. R. H. Yaldi, M. Kartiwi, N. Ismail, N. F. Za'bah, H. Mansor and A. N. Nordin, "Prototype design of smart home system using internet of things," Indonesian Journal of Electrical Engineering and Computer Science, vol. 7, no. 1, pp. 107-115, 2017.

[9] L. Kamelia, E. A. Z. Hamidi and A. J. Baskara, "E-Key Prototype Implementation Based on Short Message Service (SMS) Technology," in 12th International Conference on Telecommunication Systems, Services, and Applications (TSSA), Yogyakarta, 2018.

[10] A. Mubarok, I. Sofyan, A. A. Rismayadi and I. Najiyah, "Sistem Keamanan Rumah Menggunakan RFID, Sensor PIR dan Modul GSM Berbasis Mikrokontroler," Jurnal Informatika, vol. 5, no. 1, pp. 137-144, 2018). 